\title{
The effect of adding turmeric and artemisia herba powder to ration on productive performance of white laying hens
}

\author{
N.A. Mutlag ${ }^{1}$, M.A. Al-Norri' ${ }^{2}$ and S.M. Farhan ${ }^{3}$ \\ ${ }^{1}$ University Headquarter (naeem-admin@uofallujah.edu.iq), ${ }^{2}$ College of Veterinary Medicine (mothanavet@ \\ uofallujah.edu.iq), University of Fallujah, ${ }^{3}$ College of Agricultural (drsufian117@yahoo.com), University of Anbar, Iraq
}

(Received January 25, 2018; Accepted March 30, 2018)

\begin{abstract}
The study was aimed to improve the productive performance of white laying hens, using two types of medicinal herbs, including turmeric and Artemisia Herba. In the experiment 63 laying hens (white shevar) were used at an age of 24 weeks, hens were divided randomly in to three treatment 21 hens pre treatment with 3 replicate of 7 hens per replicate. A standard ration was used without any addition, which was considered as the control treatment (T1), the basic ration, plus turmeric powder $(0.5 \%)(\mathrm{T} 2)$, while the treatment (T3) represented the basic ration plus Artemisia Herba powder by $0.5 \%$. The study included the measurements of egg production, egg weight, feed consumption, feed conversion ratio and egg mass. The results showed a significant improvement $(\mathrm{P}<0.05)$ in the characteristics of egg production ratio, feed conversion ratio and egg mass for the treatment with the addition of Artemisia Herba flower (T3) compared with other treatments, and significant decrease $(\mathrm{P}<0.05)$ in the amount of feed consumed (T2, T3) as compared with the control treatment (T1), while the results did not show any significant differences to addition of turmeric to the ration $\left(T_{2}\right)$ in the productive performance as compared to the control treatment. It was concluded from that the addition of Artemisia Herba to the ration resulted in a significant improvement in most of the productive performance of laying hens as compared to other treatments.
\end{abstract}

Keywords: laying hens, Turmeric, Artemisia Herba

Available online at http://www.vetmedmosul.com

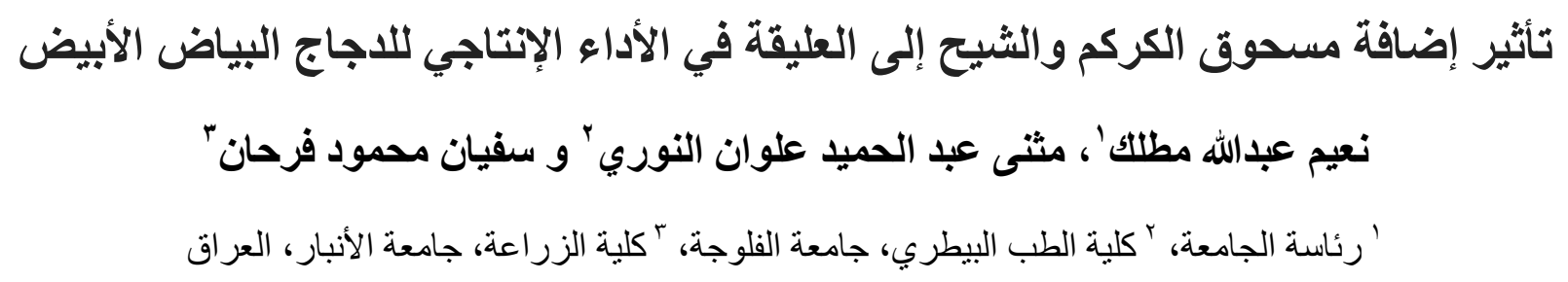

تهدف الدراسة إلى إمكانية تحسين الأداء الإنتاجي للاجاج البياض الأبيض، باستعمال نوعين من الإعشاب الطبية التي نثمل الكركم

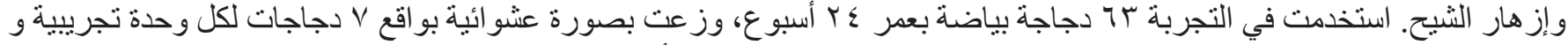

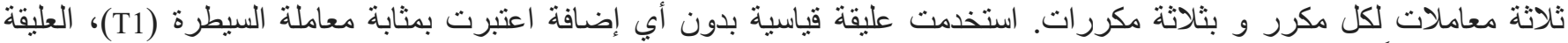

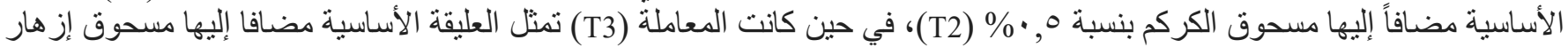

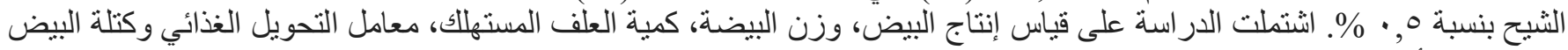

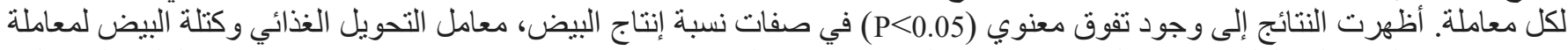

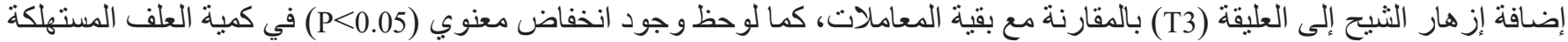

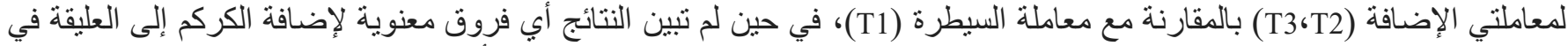

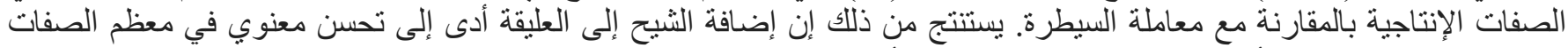
الإنتاجية للاجاج البياض الأبيض بالمعار معالمارنة مع المعاملات الأخرى. 


\section{Introduction}

Turmeric (curcuma longa linn) is a domesticated perennial herb belongs to Zingiberaceae family (1). The active material found in Turmeric include Curcumin, demethoxy Curcumin and bisdemethoxy Curcumin (2) and Tetrahydro curcuminoids (3). Joe et al. (4), reported that curcuminoids of phenolic compounds found in the roots of Turmeric are Constitute a known benefit In their impact on health and susceptibility to disease protection. In the East Asian rhizomes of Turmeric it possesses natural medical substances including antibacterial, anti-inflammatory, antineoplastic and analgesic activities because they contain Moniterpenoids, Sesquiterpenoid and curcuminoids $(5,6)$. Negi et al. (7) explained that the oil extract of turemeric oleoresin contains ar-Tumerone, Tumerone and Curlone, and its effectiveness against the microbes was observed by the pure dish method, especially Bacillus Cereus, Bacillus Coagulans, Bacillus subtilis, Staphylococcus aureus, E. coli and Pseudomonas aeroginosa. Durrani et al. (8) showed significant improvement $(\mathrm{P}<0.01)$ in body weight, weight gain and feed efficiency conversion with a significant decrease in the amount of feed consumed when adding $0.5 \%$ of Turmeric to the final ration of Broiler. Mehala et al. (9) did not noticed any significant differences from adding Turmeric to the broiler, While Musa (10) did not found significant differences in the production performance of laying hens as a result of adding Turmeric to the ration by 0.5 and $1 \%$ compared to the control treatment, so the addition of turmeric to the ration by 2 and $4 \%$ there is no indication in the production performance of laying hens (11). Artemisia Herba is attributed to the Asteraceae family (12). In general, Artemisia Herba is a long-standing herbaceous herb (13) and all types of Artemisia Herba produce aromatic oils (14). Artemisia is well known in Popular medicine, where it is used in treatment of diseases of the digestive system and respiratory and reproductive (15) and the most famous types are Cina, Annua, Absiuthium, Abrucanum, Vulgaris, Capillaris (16). The studies carried out have recorded the efficacy of Artemisia Herba extracts and the essential oil of anti-bacterial, fungal and parasitic hens (17), the researcher explained (18) antibacterial activity for a number of herbal extracts and shows the effectiveness of the essential oil of the herb against positive and negative bacteria for the chrom dye. explanation (19) The addition flowered Flowers of Artemisia Herba to a Broiler ration taken a significant effect in reducing the number of total air bacteria and numbers of colon bacteria in Intestines broiler. Also notice Nuri (20) the addation of Artemisia Herba powder into the ration by 0.25 and $0.5 \%$ gave a significantly improved the productivity of Broiler, Artemisia Herba possesses many effective antifungal compounds such as 1-butty 1-ether,1pupy1-ether Artemisia, 1-8 cinol, Artemisia These substances have shown a clear effect against many important parasite such as Toxoplasma, Babesia, Eimeria (21). Artemisia Herba herb contains the substance of santotonin, which is used naturally to kill infectious worms, especially Asciriskar (1). The addition of Artemisia Herba powder to broiler at high temperature did not improve the productive performance, while the overall health of the birds improved by reducing stress factors on birds (22). While no practical study is expected for this herb in the production performance of laying hens.

This study was conducted to know the effect of Turmeric powder and Artemisia Herba to the bush in the production performance of white laying hens.

\section{Materials and methods}

This experiment was conducted in Poultry farm of the branch of public health/ college of Veterinary medicine/ University of Fallujah for 112 days on 4 periods each period (28 days) from 1/4/2017 until 21/7/2017, 63 white laying hens (Shevar white strain, aged 24 week). Hens were divided randomly into three treatments 21 hens per treatment with 3 replicate of 7 hens per replicate. The treatment were divided as to: Treatment 1: reared on basic ration only (control), Treatment 2: reared on basic ration supplemented $0.5 \%$ Turmeric powder, Treatment 3: reared on basic ration supplemented $0.5 \%$ Artemisia Herba powder.

The hens were reared in the building containing 9 (Pen) dimensions of the $1.5 \times 1 \mathrm{~m}$ to become the area of each one $1.5 \mathrm{~m}^{2}$. Each pen represents an experimental unit, and supplied with water plastic container and a suspended plastic circular feeder. The hall was equipped with two air ventilators and used two $2500 \mathrm{~m}^{3}$ air coolers during the summer period, fodder for laying hens was provided according to the program followed by the company producing chicken throughout the experiment. The eggs were collected daily, and table (1) shows the composition of ration used in the experiment. The lighting program was 16 hours light and 8 hours of darkness a day (16 hours light starts from 6 am to $10 \mathrm{pm}$ ), and the temperature was different during the months of the experiment as shown in Table (2). Chicken has been subjected to the necessary protective vaccination program, The flock was given Group of vitamin $\mathrm{AD} 3 \mathrm{E}$ at a rate of $1 \mathrm{ml} / 2 \mathrm{~L}$ water once every two weeks and throughout the trial period.

\section{Studied parameters}

The effects of adding Turmeric powder and Artemisia Herba flowers to the ration on production performance of laying hens were evaluated by measuring; egg production, egg weight, feed consumed, the feed conversion ratio and the egg mass. The data were statistically analyzed using the SAS (23) porgram and using Complete Randomize Design 
in data analysis. The differences between the treatments were tested by using the multiple ranged Duncan test (24) and $\mathrm{P}<0.05$ and $\mathrm{P}<0.01$.

Table 1: Composition of experimental ration

\begin{tabular}{lc}
\hline Feeding materials & Percentages \% \\
\hline Yellow corn & 36.0 \\
Wheat & 28.5 \\
Soybean residue (44\% protein) & 16.0 \\
meal & 10.0 \\
*Animal protein concentrate & 7.7 \\
Calcium carbonate & 1.5 \\
Sunflower oil & 0.3 \\
Salt & 100 \\
Total & \\
\hline$* *$ Calculated chemical composition & 17.75 \\
\hline Crude protein\% & 2759 \\
Energy represented by k.cal / kg & 155 \\
Ratio of energy to protein & 0.86 \\
Lysine $\%$ & 0.41 \\
Methionine\% & 0.68 \\
Methionine + cystine $\%$ & 3.60 \\
Calcium\% $\%$ & 0.44 \\
Available phosphorus\% &
\end{tabular}

* Animal protein: Proffemy/ Jordanian origin, containing $50 \%$ crude protein, $2200 \mathrm{kcal}, 6 \%$ fat, $3.5 \%$ raw fiber, $8 \%$ calcium, 3\% phosphorus available, $2.75 \%$ lysine $1.8 \%$ methionine $2.3 \%$ methionine + cysteine, ** Calculated chemical composition of the animals according to the table of analysis of feedstuffs contained in the reports of the US National Research Council (25).
Table 2: Maximum and minimum temperature $\left(\mathrm{c}^{\circ}\right)$ inside the hall for the experimental periods

\begin{tabular}{|c|c|c|c|}
\hline Periods & Period (28) days & $\begin{array}{c}\text { Max } \\
\text { temperature } \\
\left(\mathrm{c}^{\circ}\right)\end{array}$ & $\begin{array}{c}\text { Min } \\
\text { temperature } \\
\left(\mathrm{c}^{\circ}\right)\end{array}$ \\
\hline First & $\begin{array}{l}\text { From } 1 \text { April to } \\
28 \text { April } 2017\end{array}$ & 33-35 & 26 \\
\hline Second & $\begin{array}{l}\text { From } 29 \text { April to } \\
26 \text { May } 2017\end{array}$ & $36-37$ & 29 \\
\hline Third & $\begin{array}{l}\text { From } 27 \text { May to } \\
23 \text { June } 2017\end{array}$ & 38.5 & 29 \\
\hline Fourth & $\begin{array}{l}\text { From } 24 \text { June to } \\
21 \text { July } 2017\end{array}$ & $38-39.5$ & 30 \\
\hline
\end{tabular}

\section{Results and discussion}

Table (3) indicates the effect of addition of Turmeric powder and Artemisia Herba flowers to the laying hens ration in the average egg production (H.D\%) to the existence of significant differences between the treatments, Where observed there was a significant superiority $(\mathrm{P}<0.05)$ for the addition of Artemisia Herba by $0.5 \%$ (T3) and control (T1) on the addition of Turmeric (T2) by $0.5 \%$ during the first period 28 days (T3) significantly $(\mathrm{P}<0.05)$ on the addition of Turmeric (T2) and control (T1) during second period, third and fourth period of poultry breeding. The addition of Artemisia Herba (T3) was significantly improved $(\mathrm{P}<0.05)$ on the control treatments $(\mathrm{T} 1)$ and the addition of Artemisia Herba (T3) with egg production rate for treatment $86.99,79.00$ and $78.92 \%$, respectively. These results agree with (10) that the addition of turmeric did not significantly affect the production of eggs.

Table 3: Effect of treatments on egg production (H.D\%) (mean \pm SE)

\begin{tabular}{lccccc}
\hline \multirow{2}{*}{ Treatment } & \multicolumn{4}{c}{ Periods } & \\
\cline { 2 - 5 } & First & Second & Third & Fourth & General \\
& $1 / 4-28 / 4$ & $29 / 4-26 / 5$ & $27 / 5-23 / 6$ & $24 / 6-21-7$ & Average \\
\hline (T1) Control & $86.10 \pm 2.16 \mathrm{a}^{*}$ & $84.05 \pm 2.76$ & $73.75 \pm 1.95 \mathrm{~b}$ & $72.10 \pm 1.26 \mathrm{~b}$ & $79.00 \pm 1.76 \mathrm{~b}$ \\
(T2) Add Turmeric powder $0.5 \%$ & $81.70 \pm 2.10 \mathrm{~b}$ & $81.17 \pm 1.29 \mathrm{~b}$ & $77.45 \pm 1.14 \mathrm{~b}$ & $75.37 \pm 2.16 \mathrm{~b}$ & $78.92 \pm 1.36 \mathrm{~b}$ \\
(T3) Add Artemisia Herba powder $0.5 \%$ & $87.26 \pm 2.34 \mathrm{a}$ & $87.23 \pm 1.55 \mathrm{a}$ & $87.13 \pm 3.18 \mathrm{a}$ & $86.37 \pm 2.29 \mathrm{a}$ & $86.99 \pm 0.76 \mathrm{a}$ \\
\hline
\end{tabular}

*The various small letters indicate significant differences between the treatments at the level $(\mathrm{P}<0.05)$.

As shown in Table (4), the effect of adding Turmeric powder and Artemisia Herba to the laying hens ration in the mean weight of eggs (gm) indicates no significant differences between the treatments during the four periods, the average mean weight of eggs. (T1, T2, T3) 55.84, 55.89 and 55.75 gm respectively. These results agree with (10) that the addition of turmeric by $0,5 \%$ and (11) that the addition of turmeric by $2,4 \%$ to the ration did not significantly affect the of egg weight.
Table (5) showed the effect of addition of Turmeric powder and Artemisia Herba flowers on feed of the laying hens. The feed consumption ratio showed significant differences between the treatments. A significant increase $(\mathrm{P}<0.05)$ for the control treatment $(\mathrm{T} 1)$ was observed on the addition of Turmeric (T2) by $0.5 \%$ and treatment of Artemisia Herba by $0.5 \%$ (T3) during the first, second and third periods of Breeding of birds, While there were no significant differences between different treatments during 
the fourth period of laying hens breeding in the rate of consumption feed. The control treatment (T1) was significantly showed a higher differences $(\mathrm{P}<0.05)$ for the addition of Turmeric (T2) by $0.5 \%$ and the treatment of Artemisia Herba by $0.5 \%$ (T3) Feeding consumption for treatments equal 100.27, 94.89 and 93.40 gm respectively. These results different with the researcher $(10,11)$ who indicated that there are no significant differences in average feed consumption when addition of turmeric to the ration.

Table (6) showed the effect of addition of Turmeric powder and Artemisia Herba flowers to the laying hens ration in feed conversion ratio to the existence of significant differences between treatments. There was a significant improvement $(\mathrm{P}<0.05)$ for the addition of Artemisia Herba to the broiler (T3) as compared with control treatments and the addition of Turmeric to the ration (T1, T2) during different breeding periods, It was also noticed that there were significant differences between the treatments in the general mean. There was a significant improvement $(\mathrm{P}<0.05)$ for the addition of Artemisia Herba to the ration (T3), which had a conversion ratio of 1.93 compared with control and Turmeric powder Which was the feed conversion factor of 2.26 and 2.15 respectively.These results was agree with the researcher $(10,11)$ who indicated that there are no significant differences in feed conversion ratio when addition of turmeric to the ration.

Table (7) indicates the effect of adding Turmeric powder and Artemisia Herba flowers to laying hens ration in the form of the mass of eggs (gm) to the existence of significant differences between different treatments. The table showed significant increase $(\mathrm{P}<0.05)$ for the addition of Artemisia Herba to the ration (T3) as compared with the control and Turmeric treatments to the ration (T2, T1) during different breeding periods. The same table showed significant differences $(\mathrm{P}<0.05)$ in the general effect of egg mass, with the treatment of adding Artemisia Herba to the ration the value of the egg mass reached $48.49 \mathrm{~g}$ on the control treatments and the addition of Turmeric powder to the ration equal 44.23 and 44.11 gm respectively. These results was agree with the researcher $(10,11)$ who indicated that there are no significant differences in egg mass when addition of turmeric to the ration.

Table 4: Effect of treatments on egg weight $(\mathrm{gm})($ mean \pm SE)

\begin{tabular}{|c|c|c|c|c|c|}
\hline \multirow[b]{2}{*}{ Treatment } & \multicolumn{4}{|c|}{ Periods } & \multirow[b]{2}{*}{$\begin{array}{l}\text { General } \\
\text { Average }\end{array}$} \\
\hline & $\begin{array}{c}\text { First } \\
1 / 4-28 / 4\end{array}$ & $\begin{array}{c}\text { Second } \\
29 / 4-26 / 5\end{array}$ & $\begin{array}{c}\text { Third } \\
27 / 5-23 / 6\end{array}$ & $\begin{array}{c}\text { Fourth } \\
24 / 6-21-7\end{array}$ & \\
\hline (T1) Control & $55.58 \pm 0.39 \mathrm{a}^{*}$ & $55.58 \pm 0.55$ & $55.92 \pm 0.19$ & $56.01 \pm 1.37$ & $55.84 \pm 0.65$ \\
\hline (T2) Add Turmeric powder $0.5 \%$ & $55.92 \pm 0.90$ & $55.90 \pm 1.20$ & $55.85 \pm 1.35$ & $55.92 \pm 0.95$ & $55.89 \pm 1.75$ \\
\hline (T3) Add Artemisia Herba powder $0.5 \%$ & $56.01 \pm 0.36$ & $55.40 \pm 1.28$ & $55.75 \pm 0.81$ & $55.83 \pm 0.73$ & $55.75 \pm 1.15$ \\
\hline
\end{tabular}

*The various small letters indicate significant differences between the treatments at the level $(\mathrm{P}<0.05)$.

Table 5: Effect of treatments on feed consumption (gm/hens/day) (mean \pm SE)

\begin{tabular}{|c|c|c|c|c|c|}
\hline \multirow[b]{2}{*}{ Treatment } & \multicolumn{4}{|c|}{ Periods } & \multirow[b]{2}{*}{$\begin{array}{l}\text { General } \\
\text { Average }\end{array}$} \\
\hline & $\begin{array}{c}\text { First } \\
1 / 4-28 / 4 \\
\end{array}$ & $\begin{array}{c}\text { Second } \\
29 / 4-26 / 5 \\
\end{array}$ & $\begin{array}{c}\text { Third } \\
27 / 5-23 / 6\end{array}$ & $\begin{array}{c}\text { Fourth } \\
24 / 6-21-7 \\
\end{array}$ & \\
\hline (T1) Control & $106.24 \pm 1.7 \mathrm{a}^{*}$ & $110.62 \pm 1.92 \mathrm{a}$ & $93.11 \pm 0.89 \mathrm{a}$ & $91.12 \pm 1.63$ & $100.27 \pm 1.78 \mathrm{a}$ \\
\hline (T2) Add Turmeric powder $0.5 \%$ & $101.16 \pm 1.84 \mathrm{~b}$ & $102.41 \pm 2.09 \mathrm{~b}$ & $86.73 \pm 0.96 b$ & $89.25 \pm 0.74$ & $94.89 \pm 1.04 \mathrm{~b}$ \\
\hline (T3) Add Artemisia Herba powder $0.5 \%$ & $99.17 \pm 1.44 \mathrm{~b}$ & $98.66 \pm 1.16 \mathrm{~b}$ & $86.37 \pm 1.12 b$ & $89.40 \pm 1.12$ & $93.40 \pm 1.32 \mathrm{~b}$ \\
\hline
\end{tabular}

*The various small letters indicate significant differences between the treatments at the level $(\mathrm{P}<0.05)$.

Table 6: Effect of treatments on $\mathrm{n}$ feed conversion ratio (mean $\pm \mathrm{SE}$ )

\begin{tabular}{lccccc}
\hline \multirow{2}{*}{ Treatment } & \multicolumn{4}{c}{ Periods } & \\
\cline { 2 - 5 } & First & Second & Third & Fourth & General \\
& $1 / 4-28 / 4$ & $29 / 4-26 / 5$ & $27 / 5-23 / 6$ & $24 / 6-21-7$ & Average \\
\hline (T1) Control & $2.22 \pm 0.11 \mathrm{a}^{*}$ & $2.36 \pm 0.22 \mathrm{a}$ & $2.25 \pm 0.14 \mathrm{a}$ & $2.25 \pm 0.05 \mathrm{a}$ & $2.26 \pm 0.01 \mathrm{a}$ \\
(T2) Add Turmeric powder 0.5\% & $2.21 \pm 0.23 \mathrm{a}$ & $2.22 \pm 0.09 \mathrm{a}$ & $2.01 \pm 0.11 \mathrm{a}$ & $2.12 \pm 0.09 \mathrm{a}$ & $\mathrm{a} 2.15 \pm 0.08 \mathrm{a}$ \\
(T3) Add Artemisia Herba powder $0.5 \%$ & $2.03 \pm 0.13 \mathrm{~b}$ & $2.04 \pm 0.11 \mathrm{~b}$ & $1.78 \pm 0.09 \mathrm{~b}$ & $1.85 \pm 0.05 \mathrm{~b}$ & $1.93 \pm 0.07 \mathrm{~b}$ \\
\hline
\end{tabular}

*The various small letters indicate significant differences between the treatments at the level $(\mathrm{P}<0.05)$. 
Table 7: Effect of treatments on egg mass $(\mathrm{gm})(\mathrm{mean} \pm \mathrm{SE})$

\begin{tabular}{lccccc}
\hline \multirow{2}{*}{ Treatment } & \multicolumn{4}{c}{ Periods } & \\
\cline { 2 - 5 } & First & Second & Third & Fourth & General \\
& $1 / 4-28 / 4$ & $29 / 4-26 / 5$ & $27 / 5-23 / 6$ & $24 / 6-21-7$ & Average \\
\hline (T1) Control & $47.85 \pm 2.12 \mathrm{a}^{*}$ & $46.94 \pm 1.32 \mathrm{~b}$ & $41.24 \pm 0.19 \mathrm{~b}$ & $40.38 \pm 0.61 \mathrm{~b}$ & $44.23 \pm 0.62 \mathrm{~b}$ \\
(T2) Add Turmeric powder 0.5\% & $45.68 \pm 2.01 \mathrm{~b}$ & $45.37 \pm 0.85 \mathrm{~b}$ & $43.25 \pm 0.57 \mathrm{~b}$ & $42.14 \pm 1.91 \mathrm{~b}$ & $44.11 \pm 1.13 \mathrm{~b}$ \\
(T3) Add Artemisia Herba powder 0.5\% & $48.87 \pm 1.93 \mathrm{a}$ & $48.32 \pm 1.00 \mathrm{a}$ & $48.57 \pm 2.28 \mathrm{a}$ & $48.22 \pm 1.62 \mathrm{a}$ & $48.49 \pm 1.03 \mathrm{a}$ \\
\hline
\end{tabular}

*The various small letters indicate significant differences between the treatments at the level $(\mathrm{P}<0.05)$.

The reduced amount of feed consumed for laying hens during the period of breeding when adding Turmeric to the ration might be due to the active substances in Turmeric, which has an antioxidant activity $(26,27)$ which stimulate protein synthesis by the enzymatic system of birds (3) Turmeric also possesses on effective anti-bacterial and inflammatory properties (6) and is characterized by its effectiveness against microbes, especially phylococcus aureusSta, E.coli and Psedomononas (7). This is reflected positively on the health status of birds through their ability to balance the content of the microbiology of the digestive system, which makes better use of feed by the bird than it is for the microorganisms living in that area in its natural state $(28,29)$, Turmeric possesses substances that are clearly effective in influencing innate toxins resulting from Parasiticus Aspergillus through its effect on the causative postively (30) and therefore improving the nutritional value of ration. The significant improvement of the productive qualities of laying hens feed on a ration supplemented with Artemisia Herbha powder may return to flavonoids, it is one of the active compounds in the herb which have a vital and important role by improving the metabolic and health status of the body, and reducing the risk of disease. and these compounds are highly effective antioxidants, leading to the protection of some representative materials by elimination of free radicals and their histological effect $(31,32)$, as well as containing Artemisia Herba on the components of Bitter, which urges the secretions of the salivary glands and digestive organs in their secretions leading to improved digestion and subsequent nutrient uptake (16). other factors that have improved the productive properties of layering hens contain Artemisia herb Herba pilot oil (abrotanin and tannic acid)) which support gastrointestinal function due to increased gastrointestinal and gastric secretions (33), studies have also shown that Turmeric has anti-bacterial, parasitic and fungal effect (17). The (19) confirmed that the herb of Artemisia Herba flowers had a significant effect in reducing the number of harmful bacteria in the intestines of Broiler. It was concluded that the addition of the Artemisia Herba powder to the ration resulted in an improvement in the production performance of white laying hens, while the addition of turmeric resulted in a significant decrease in the amount of feed consumed.

\section{References}

1. Shakly MKO. Dictionary of herbs and common diseases and herbal medicine. Al- Rayyan Foundation for Printing, Publishing and Distribution, $2^{\text {nd }}$ Floor, Beirut, Lebanon. 2006.

2. Wuthi- Udomler M, Grisanapan W, Luanratana O, Caichompoo W. Anti- fungal activities of plant extracts. Southeast Asian J Trop Med Public Health. 2000;3(Supp 1):178-182.

3. Osawa T, Sugiyama Y, Inayoshi M, Kawakishi S. Antioxidative activity of tetrahydrocurcuminoids. Biosci. Biotechnol Biochem 1995;59(9):1609-1612.

4. Joe B, Vijaykumar M, Lokesh B R. Biological properties of curcumincellular and molecular mechanisms of action Crit Rev Feed Sci Nutr. 2004;44(2):97-111.

5. Tang W, Eisenbrand, G. Chinese drugs of plant origin. Springerverlag: Berlin and Heidelberg, Germany. 1992; pp:401-415.

6. Fang J Y, Hung CF, Chiu HC, Wang J J, Chan T F. Efficacy and irritancy of enhancers on the in-vitro and in-vivo percutaneous absorption of curcumin. J Pharm Pharmacol. 2003;55(5):593- 601.

7. Negi P S, Jayaprakasha G K, Jagan Mohan Rao L, Sakariah K K. Antibacterial activity of turmeric oil: a byproduct from curcumin manufacture. J Agric Food Chem. 1999;47(10):4297-4300.

8. Durrani FR, Ismail M, Sultan ASM, Suhail NCh, Durrani Z. Effect of different levels of feed added Turmeric (Curcuma longa) on the performance of Broiler chicks. J Agric Biol Sci. 2006;1(2):9-11.

9. Mehala C, Moorthy M. Production performance of broilers fed with Aloe Vera and curcuma longa (Turmeric). Int $\mathrm{J}$ Poult Sci. 2008;7(9):852- 856.

10. Musa B H. Effect of adding garlic, turmeric, thyme and bio-booster (Imbo) to the laying of hens (Shaver) in the production performance and some blood characteristics at different temperatures. PhD Dissertation- Poultry Nutrition- College of Agriculture- Anbar University (2012).

11. Hassan SM. Effects of adding different dietary levels of Turmeric (Curcuma longa Linn) powder on productive performance and egg quality of laying Hens. Int J Poult Sci. 2016;15(4):156-160.

12. Subramoniam A, Pushpangadan P, Rajasekharan S, Evans D A, Latha P G, Valsaraj R. Effects of Artemisia pallens wall. on blood glucose levels in normal and alloxan-induced diabetic rat. J Ethnopharmacol. 1996;50(1):13-17.

13. Watson LE, Bates PL, Evans TM, Unwin MM, Estes JR. Molecular phylogeny of subtribe Artemisinae (Asteraceae), including Artemisia and its allied and segregate genera. BMC Evol Biol. 2002;2(17):1-12.

14. Ling YR. The old world Artemisia linn. (compositae). Bull Bot Res. 1992;12:1-108.

15. Rai MK, Acharya D, Wadegaonkar R. Plant derived- antimycotics: potential of Asteraceous plants. In: plant- derived antimycotics: current trends and future prospects, Haworth press. New York, London, Oxford, 2003; pp:165-185. 
16. Chevalier A. Alternative Medicine. Medicinal herbs and medicinal plants. Copyright Arabic. Academia International., 1996.

17. Kalemba D, Kusewicz D, Swiader K. Antimicrobial properties of the essential oil of Artemisia Asiatica Nakai. Phytother Res. 2002;16(3):288-291.

18. Al-Shbail NA. Antibacterial activity of some plant extracts from AlMafraq area. M.Sc. Dissertation, College of Science and Arts. University of Ul-Abait. 2003.

19. Al- Noori MA, Al-Ain IA, Al-Rawi SThJ. Effect of supplementation Artemisia herba, Curcuma longa, Thymus vulgaris and Nigella sativa in diet on some microbial character of broiler chicken. Tikrit University J Agric Sci. 2011;11(4):366-380.

20. Al-Nouri MA. Effect of adding different concentrations of Nigella sativa and Artemisia Herba powder and their combination in the ration on productive performance of Broiler Anbar J Vet Sci. 2012;5(2):177187.

21. Vicidomini S. Properties of alternative plant extractor of Artemisia (Asteraceae) as anti protozoa, ilNatu. Campano. 2007;15:1-9.

22. Arabi EA, Elagib HAA, Dousa BM, Malik HEE, Elamin KM. Effect of Supplementation of Artemisia Herba-Alba (Shih) on the Performance of Broiler Chicks J Anim Sci Adv. 2016;6(9):1749-1755.

23. SAS. SAS User's Guide: Statistical System, Inc. Cary NC. USA. 1996.

24. Duncan D. Multiple range and multiple F-test. Biometrics. 1955;11:124.
25. National Research Council (NRC). Nutrient Requirement of poultry. $9^{\text {th }}$ ed. National Academy press, Washington. 1994.

26. Ruby AJ, Kuttan G, Babu KD, Rajasekharan KN, Kuttan R. Antitumor and antioxidant activity of natural curcuminoids. Cancer let. 1995;94(1):79-83.

27. Sreejayan RMN. Curcuminoids as potent inhibitors of lipid peroxidation. J Pharm Pharmacol. 1994;46(12):1013- 1016.

28. Jones FT, Ricket SC. Observations on the history of the development of antimicrobials and their use in poultry feeds. Poult Sci. 2003;82(4):613-617.

29. Rahmani HR, Speer W. Natural additives influence the performance and Humoral immunity of broilers. Int J Poult Sci. 2005;4(9):713-717.

30. Soni KB, Rajan A, Kuttan R. Reversal of aflatoxin induced liver damage by turmeric and curcumin. Cancer Lett. 1992;66(2):115-121.

31. Nantz MP, Rowe CA, Nieves CJr, Percival SS. Immunity and antioxidant capacity in human is enhanced by consumption of a dried, encapsulated fruit and vegetable juice concentrate. $\mathrm{J}$ Nutr. 2006;136(10):2606-2610.

32. Yamamoto A, Gaynor D. Therapeutic potential of inhibition of the NF-KappaB pathway in the treatment of inflammation and Cancer. J Clin Invest. 2001;107(2):135-142.

33. Remberg P, Bjork L, Hedner T, Sterner O. Characteristics, Clinical effect profile and tolerability of a nasal spray preparation of Artemisia abrotanum L. for allergic rhinitis. Phytomedicine. 2004;11(1):36-42. 